Marina MacKay

\title{
MURIEL SPARK AND SELF-HELP
}

'I have always been free with advice', announces narrator Nancy Hawkins in Muriel Spark's A Far Cry from Kensington (1988), 'but it is one thing to hand out advice and another to persuade people to accept it'. ${ }^{1}$ Nancy is full of useful wisdom, as when she shares her views on willpower: 'I offer this advice without fee; it is included in the price of this book'. ${ }^{2}$ Thus, we learn that 'you should think of will-power as something that never exists in the present tense, only in the future and the past. At one moment you have decided to do or refrain from an action and the next moment you have already done or refrained; it is the only way to deal with will-power'. ${ }^{3}$ The idea of purchasing advice in a book returns when Nancy offers 'free of charge' her views on how to produce a first novel as though you were writing a letter to a friend: 'Write privately, not publicly; without fear or timidity, right to the end of the letter, as if it was never going to be published, so that your true friend will read it over and over, and then want more enchanting letters from you' ${ }^{4}$ Spark's whole body of fiction is full of mottos, mantras, and maxims, from Nicholas Farringdon's unsellable book of aphorisms in The Girls of Slender Means (1963) to Fleur Talbot's portable reflections on literature and life in Loitering with Intent (1981), another novel that looks back to the beginning of Spark's writing career. This essay considers Spark's fiction alongside one of the major publishing phenomena of these novels' mid-century setting: a golden age for the self-help bestseller. With that context in mind, I argue that Spark invites us to consider what transmissible 
wisdom can be found in a novel. Or, to recall the folk phraseology of her own novels, does her fiction leave us any the wiser?

Certainly some readers have thought so. Frank Kermode wrote in 2004 that Spark writes as though 'one of the prime duties of the artist is to clear away as much as possible of the monstrous accumulation of stupidity in our world. Hence a certain ruthlessness of tone, a steady refusal to countenance failures of common sense'. ${ }^{5}$ Discussions of truth and wisdom in Spark's fiction invariably return to the non-negotiable verities of God - as, indeed, they do in Kermode's excellent essay. ${ }^{6}$ In fact, and perhaps even in self-conscious acknowledgement of the contemporary critical tendency to read Spark primarily as a Roman Catholic writer, her semi-autobiographical Fleur Talbot reflects on the relationship between secular and spiritual wisdom, when she recalls filling her childhood copybook with such saws as 'Necessity is the Mother of Invention':

Another maxim was All is not Gold that Glisters, and another was Honesty is the Best Policy, and I also recall Discretion is the Better Part of Valour. And I have to testify that these precepts, which I was too flighty-minded to actually ponder at the time, but around which I dutifully curled my cursive Ps and my Vs, have turned out to my astonishment to be absolutely true. They may lack the grandeur of the Ten Commandments but they are more to the point. ${ }^{7}$

In keeping with this comic contrast between the utility of ordinary social wisdom and the comparative irrelevance of Mosaic injunctions, I suggest in what follows that Spark's fiction shows a more everyday concern with practical wisdom when, as Kermode has it, she tries to leave the world a little less stupid than she found it. 
Yet at least since Walter Benjamin's elegiac essay 'The Storyteller' (1936), it has been a truism that novels have nothing to do with wisdom. For Benjamin, famously, wisdom was the unique province of storytelling, a product of older, rooted communities in which living oral traditions were still available. In 'The Storyteller', we are told that 'every real story ... contains something useful. The usefulness may, in one case, consist in a moral; in another, in some practical advice; in a third, in a proverb or maxim. In every case the storyteller is a man who has counsel for his readers' ${ }^{8}$ In contrast, the novel is the work of 'the solitary individual, who is no longer able to express himself by giving examples of his most important concerns, is himself uncounselled, and cannot counsel others'. ${ }^{9}$ If Spark's novels seldom have 'a moral' - although her Memento Mori (1959) wears its moral on its very dustjacket in the titular directive to keep one's death ever in mind - they are never short of 'practical advice', 'proverbs' and 'maxims'. In his influential revaluation of 'The Storyteller', Peter Brooks has argued that novels cannot help investigating the possibility of communicating wisdom because 'the result aimed at by plotting is in some large sense ever the same: the restoration of the possibility of transmission'. ${ }^{10}$ Thus, for example, Brooks reads the Victorian novel's concern with familial generations as a way to 'play out repeatedly and at length the problem of transmission ... asking where an inheritable wisdom is to be found'; the same interest also explains the nineteenth-century taste for narrative framing, 'which, dramatizing the relations of tellers and listeners, narrators and narratees, regularly enacts the problematic of transmission'. ${ }^{11}$

What Brooks terms 'the problematic of transmission' features in Spark's fiction in an even more literal way. We might think of the convent's bugged trees in The Abbess of 
Crewe (1974), for example, or the cryptic and anonymous voices that haunt characters by typewriter or telephone in The Comforters (1957) and Memento Mori. And while she is much less interested in familial inheritances than Brooks's nineteenth-century novelists, the idea of wisdom that is transmissible within and across generations is everywhere in her concern with guides and mentors. Miss Jean Brodie is unusual among Spark's advicegivers in that her advice actually gets someone killed, when she encourages delinquent Joyce Emily to fight for General Franco's fascists. Nonetheless, givers of bad advice populate her fiction, starting with the proverbially unhelpful Job's comforters of The Comforters, who reappear in another form decades later in The Only Problem (1984). Across her career, Spark asks readers to consider what distinguishes good advice from bad. By recalling so often the dynamics of the self-improvement enterprise, she addresses both the novel's role in the cultivation of intelligence and discrimination - or how it 'bring[s] about a mental environment of honesty and self-knowledge', as she defined the purpose of literature in one of her best-known essays - and the novel's relationship to what she termed 'that greatest of all the arts and sciences, daily life'. ${ }^{12}$

In a characteristically self-reflexive irony, Spark's fiction is full of snake oil merchants, all promising edification and revelation. 'I give rare advice', announces Dougal Douglas, the mischief-making protagonist of The Ballad of Peckham Rye (1960), who, in the space of a single advisory session with his employer, mimics 'the analyst', 'a lady-columnist', and a 'medium of the spiritualist persuasion'. ${ }^{13}$ Dougal has a sinister double in Patrick Seton, the fraudulent spiritualist medium of The Bachelors (1960), while January Marlow in Robinson (1958) shares a remote island with Tom Wells, editor of a New Age magazine and a friend of 'distinguished psychometrists, clairvoyants, 
Karma interpreters, astrologers, yoga spiritualists, divine healers, astral radiesthetists, saliva prognosticators'. ${ }^{14}$ Tom makes a career peddling occult wisdom and blackmailing the vulnerable people who reveal their secrets to him. But January, like all Spark's firstperson narrators, also has wisdom she wants to share, even on such recherché matters as how to teach your cat to play ping-pong, answering at some length a question that few people must have ever asked. However, January's advice that 'when travelling abroad alone, it is wise and actually discreet to take up with one well-chosen man on the journey' takes on a brutally ironic cast retrospectively, when Lise in Spark's The Driver's Seat (1970), sets out to pick up her own murderer on vacation. ${ }^{16}$ In this novel, too, we find a false guru: Lise's travelling companion Bill promises enlightenment to followers of his macrobiotic cult. At the late end of Spark's career, the main character in Aiding and Abetting (2000) is a fake stigmatic turned fashionable psychoanalyst. As Beate Pappenheim, she defrauds the Roman Catholic faithful; as Dr Hildegarde Wolf, her expensive therapeutic novelty of talking primarily about herself becomes her unique selling point for a wealthy clientele.

Given Spark's interest in these entrepreneurial fraudsters, it is hard not to think that she would have enjoyed the mid-century phenomenon of the wish-yourself-wealthy bestseller, from Napoleon Hill's Think and Grow Rich (1937) to Norman Vincent Peale's The Power of Positive Thinking (1952). Dale Carnegie's How to Win Friends and Influence People (1936) is among the classic examples: his self-styled 'practical, working handbook on human relations' is essentially a manual for converting emotional intelligence into hard cash. ${ }^{17}$ Still, the many self-help books addressed to women are perhaps more relevant for thinking about Spark's fiction, since they are typically more 
interested in the novelistic business of everyday life. A few of these books are, it is true, as instrumentally wealth-directed as those directed primarily at men. For a start, Dale Carnegie never wrote anything quite so cynical as his second wife Dorothy's How to Help Your Husband Get Ahead in His Business and Social Life (1954). A charitable reading would characterize this book as advocacy for shared marital goals: 'Help Him Decide Where He Is Going' and 'When One Goal Is Reached - Set Up Another' are the exhausting titles of the book's opening chapters. ${ }^{18}$ 'Is your husband prepared for promotion?' Mrs Carnegie asks later in her manual of backseat driving: 'If not, what is he doing about it? And what are you, his wife, doing about it? ${ }^{19}$ The book is fundamentally about how to manipulate your useless husband into earning more money by, for example, covertly making him appear likeable to colleagues and acquaintances, however unpleasant they might initially find him. This is not so much a self-improvement programme as a programming of your unwitting spouse.

A friend of Dorothy Carnegie, the silent-era actress turned advice writer Margery Wilson had undertaken an ostensibly similar project for men, although the salutary subtext of How to Make the Most of Wife (1951) is that mid-century husbands should look to themselves if they find their spouses lacking in truly feminine loyalty and devotion. Her much-updated bestseller The Woman You Want to Be: Margery Wilson's Complete Book of Charm is more directly relevant to Spark's fiction. The 1944 iteration suggests the general inspiration for Selina's savagely effective poise course in Spark's The Girls of Slender Means, which is set soon afterwards in the spring and summer of 1945. To the merriment of the younger and less sophisticated residents of the May of Teck club, beautiful Selina has paid five guineas for a correspondence course on poise 
that requires her to recite 'Two Sentences' twice a day for the purposes of autosuggestion: 'Poise is perfect balance, an equanimity of body and mind, complete composure whatever the social scene. Elegant dress, immaculate grooming, and perfect deportment all contribute to the attainment of self-confidence'. ' $A N Y O N E$ CAN LEARN POISE', blares one of Wilson's subheadings: 'People who have poise know they have it. It is their best friend in society'. ${ }^{21}$ Selina may also have benefitted from the maxim immediately prior to this one: 'THE LANGUID WOMAN'S APPEAL' - Selina is always portrayed as (in Wilson's description) 'the languorous, graceful woman who can draw a circle of admirers into the most secluded corner' ${ }^{22}$ Thus we find Selina silent amid a group sitting with her 'long unsurpassable legs arranged ... diagonally from the deep chair where she lolled in the distinct attitude of the only woman present who could afford to loll. There was something about Selina's lolling which gave her a queenly eminence'. ${ }^{23}$ Indeed, the narrator records Selina's 'languid manner' immediately prior to describing her poise sentences for the first time. ${ }^{24}$ A character in Spark's play Doctors of Philosophy (1963) likewise strikes costumed poses for all occasions - the first act closes with her leaving the stage to "change into something suitable for gazing across the canal by dusk', and the second opens with her writing letters in romantic bedroom attire, 'specially suitable for ... writing letters', although this depends upon 'what sort of letters you write'. 25

Wilson's The Woman You Want to Be is full of portable precepts, always capitalised and in italics. They cover everything from your bodily carriage - 'CHEST UP FOR MAGNETISM' - to your small talk: 'ONLY TWO OPINIONS AN EVENING'. ${ }^{26}$ (Wilson must have either encountered or expressed one dinner-party opinion too many 
prior to her 1952 follow-up, You're as Young as You Act, in which you may 'ALLOW YOURSELF ONE OPINION AN EVENING'..27 Spark's amused interest in such social wisdom survives even to her final novel, The Finishing School (2004), where conventions are generally upended by Nina's pronouncements in what she calls her 'comme il faut class' at College Sunrise ('Try not to look very well brought up, it's awful'). ${ }^{28}$

It is against such oppressive productions as Wilson's about female self-stylisation ('IS YOUR LAUGHTER GETTING MIDDLE-AGED?' 'STIFF WRISTS LOOK OLD') that the best of the popular mid-century self-help writers stand out like beacons of bright intelligence. ${ }^{29}$ Unlike the self-help millionaires promising transformative wealth or charisma, advice writers such as Marjorie Hillis and Leonora Eyles attend instead to ordinary happiness and self-reliance. Some of Hillis's advice reflects in substance the characteristic cosmetic preoccupations of the women's self-help book, although they seldom recall its style ('Don't worry about whether your nightgowns will wear if you are sure that they will flatter'). ${ }^{30}$ More usually, her epigrams are directed towards personal satisfactions rather than social obeisance, as when we learn that 'independence, more truthfully than virtue, is its own reward ${ }^{31}$ As Lisa Hilton puts it in her foreword to Virago's 2005 reprint of Hillis's sensationally successful first book Live Alone and Like It (1936), 'Personal improvement, the Live Alone way, is not nurturing one's self-esteem like a sick puppy, but taking an honest look at one's failings of character and appearance, and doing something about them. ${ }^{32}$ This fortifying approach proves more cheerful than it sounds, because Hillis sees personal improvement not as some kind of pseudo-moral project but as the pursuit of a resilient and realistic independence. 
Since Hillis was a clergyman's daughter - indeed, we learn from Dale Carnegie's biographer that her father's writings were among Carnegie's early influences - the antipuritanical panache that she brings to bracing self-reliance is all the more striking. ${ }^{33}$ The spritely Orchids on Your Budget (1938) is about cultivating not simply fulfillment but delight on relatively slender means:

If you keep your standards up, even though your salary goes down, it can have an air, which will be all the more impressive because of the courage behind it. You can also have gaiety and charm and chic, if you are ready to substitute the trouble they take for the cash they cost.

Or you can just settle down and let things go to pieces around you. You'll have lots of company. ${ }^{34}$

Hillis has no time for 'the spiritless way in which so many people accept what they refer to as their "lot in life". ${ }^{35}$ The question is how to take control of your life in order to render financial constrictions less demoralising. Budgeting is necessary, we learn, 'after one of those Lessons of Life learned from being caught short because of an illness or a slump in the stock market or a love affair that called for some knock-out clothes' ${ }^{36}$ To budget, you need to work out what you consider essential, but there are 'a thousand variations in lists of Necessities, depending on locality, size of family, standards, interests, and whether or not you're a Noble Character. ${ }^{37}$ Noble Characters presumably enjoy philanthropic concerns and take no interest in everyday pleasures of the sort that Hillis's book aims to help her readers attain.

A former editor at Vogue, a magazine that counted couture-loving Spark among its readers, Hillis is intelligent, sophisticated, and often arrestingly funny. What she isn't 
at all is high-minded; for that we would go to her exact contemporary, the novelist and advice-writer Leonora Eyles. Eyles was very much the Noble Character: a pacifist and vegetarian Christian socialist whose advice is invariably underwritten by her conviction that structural social changes would remove the problems that fill the advice-writer's mailbag. For Eyles, problems of sexual, marital, and family relationships are not so much psychological phenomena as problems of housing, childcare, and organised recreational opportunities. She also insists on the importance of seeing private difficulties in their historical perspective: for example, it is in the unlikely context of the manual Sex for the Engaged (1952) that we are told that people cannot be blamed for their lack of commitment to their 'drifting relationships' in an era when 'treaties between nations are torn up. ${ }^{39}$

Even the title of her Is Your Problem Here? (1947) speaks to Eyles's fundamentally sociological and generic approach. In contrast, Hillis is almost a novelist manqué: she is not remotely interested in what people ought to want - you are either a Noble Character or you are not - but in the reader knowing what she wants for herself. Insofar as there is any programmatic element to Hillis's thought it is her commonsensical feminism. Witness the case of Mrs $U$ and what we would now think of as her controlling husband. Although not abusive in ways that a mid-century court would recognise, he maintains his domestic authority through 'humiliating' financial arrangements that give his wife no individual spending power. ${ }^{40}$ Mrs $U$ has enjoyed so little fiscal autonomy that even when she wishes to leave him, she lacks the practical knowledge to proceed: 'It almost looked as if she would have to choose between starvation and Mr. U. After some consideration, she decided to try starvation'. ${ }^{41}$ 
Written after her husband's death, Hillis's You Can Start All Over (1951) is understandably a more sober affair at times. Even so, there is plenty of mischief and tart humour, as when Hillis warns newly single women about unwanted sexual passes from their friends' formerly reliable husbands: 'Our advice is not to take it that seriously. After all, you don't have to go along with the gentleman's idea, and a well-timed insult can do wonders for a woman's morale, especially after forty'. ${ }^{42}$ We learn later in the book that widows are much less inclined to remarry than widowers: 'Those who were happy are afraid it can't happen twice; those who weren't are afraid it can' ${ }^{43}$ Spark's writing shares this worldly and aphoristic quality, particularly when, like Hillis, she ironises the ludicrous postures that some women feel socially obliged to strike. The academic Leonora in Doctors of Philosophy must act the frustrated spinster as counterpoint to her cousin Catherine's pretended sexual conformity. 'I like to please men', Catherine tells her: 'Do you think it pleases a man when he looks into a woman's eyes and sees a reflection of the British Museum Reading Room? ${ }^{44}$

Without exception, Spark's novels about girls and women - most famously The Prime of Miss Jean Brodie - are also novels about advice. In her autobiography Curriculum Vitae (1992), Spark wrote with only affectionate irony about the axioms of her Edinburgh girlhood, 'where cleanliness and godliness shook hands with each other, honesty was the best policy, all was not gold that glistered and necessity was the mother of invention': these 'maxims' offered 'a sense of security which the precarious economic position of the country could not shake'. ${ }^{45}$ Against this cultural background, the question of 'security' helps to explain the difference between the official tenets of the Marcia Blaine School and the outlaw spirit of Miss Jean Brodie's competing wisdom. For 
headmistress Miss Mackay's maxims, Miss Brodie has counter-maxims, as when she explains that "Miss Mackay ... believes in the slogan "Safety First." But Safety does not come first. Goodness, Truth and Beauty come first ${ }^{46}$ Miss Mackay abides by traditional wisdom: 'What canna be cured maun be endured', she laments, in accordance with her 'habit of putting the universal wise saws into Scots dialect to make them wiser' ${ }^{47}$ In contrast, Miss Brodie is full of altogether arbitrary rules on such matters as how far a window may be opened: 'Six inches is perfectly adequate. More is vulgar'. ${ }^{48}$ (Speaking of vulgar, readers who suspect sexual innuendo might note that this dictum immediately precedes Miss Brodie's comments on the sexless 'sublime love' of Dante and Beatrice. $)^{49}$ In addition to inventing her own axioms, Miss Brodie has an unsurpassed talent for misusing the conventional ones. That silence is golden and discretion the better part of valour get comprehensively repurposed to praise the girls for not letting on to Miss Mackay that their class period has been spent on Miss Brodie's fabricated account of a past romance, or that the apples they are eating have come from the orchard of her present lover, the music teacher Mr Lowther. ${ }^{50}$ She makes the scriptural aphorism 'where there is no vision, the people perish' license her indifference to everyday norms only by ripping it from a context that gives it exactly the opposite meaning. ${ }^{51}$ According to Proverbs 29:18, 'Where there is no vision, the people perish: but he that keepeth the law, happy is he'.

A Far Cry from Kensington is even more explicitly about self-help. Set in 1954, the plot turns on the pseudo-science of radionics, when a character who does not know that Nancy Hawkins is dieting believes that her radionic device has given Nancy a deadly wasting disease. Late in the novel, Nancy mentions the trial of radionics entrepreneur 
George de la Warr in June 1960; this legal action undertaken by an unsatisfied customer failed when the judge concluded that although radionics was scientifically nonsensical, no one had been defrauded because the vendors sincerely believed that it worked. 'The Sixties echoed continuously to such things', wrote journalist Bernard Levin in 1970, when he discussed this widely covered trial in his survey of the previous decade. ${ }^{52}$ This was 'a credulous age, perhaps the most credulous ever', Levin proclaimed, 'and any philosophy, from Zen Buddhism to macrobiotics and from violence as an end in itself to total inactivity as an end in itself, could be sure of a respectful hearing and a group of adherents, ${ }^{53}$

Spark backdates to the 1950 s a resurgence of anti-rational interests - 'probably as a result of the uncontemplatable events which had blackened the previous decade', according to Nancy Hawkins - but against occult forms of wisdom are set Nancy's own real-world pronouncements. ${ }^{54}$ The novel opens with her advice on exploiting sleeplessness, for 'the quality of insomnia depends entirely on what you decide to think of ${ }^{55}$ Nancy subsequently advises on matters as various as how to get a new job; on the utility of bananas for rheumatism and cats for concentration; on how to say no to unreasonable requests and how to manage a high volume of non-urgent correspondence. ${ }^{56}$ Meanwhile, even the novel's most minor characters have their own definite rules to live by. 'The less you put on paper the better' is among landlady Milly's maxims; the 'unconventional advice which savoured of officers'-mess lore' of Nancy's employer Martin York includes his insistence that the way to deal with the Inland Revenue is to confuse them with spontaneous cheques for arbitrarily selected sums; Nancy's next employer Ian Tooley places his faith in astrology and 'would put all trouble and vexation 
down to the stars rising in a certain sign or a phase of the moon'; colleague Colin Shoe is full of what Nancy calls his 'regular maxims' about books and authors. ${ }^{57}$ No fewer than three times is the unnamed judge who sentences Martin York for fraud attributed the axiom that 'Commercial life cannot be carried on unless people are honest'. ${ }^{58}$ Even a character as ancillary as Nancy's fellow lodger Kate Parker is identified with her 'appropriate observations of a moral order, so typical of Kate' ${ }^{59}$ Kate serves no plot function, but she is as much a self-help heroine as Nancy. In fact, she resembles one in an unusually literal sense: "with her good little boxes marked "bus-fares", "gas", "sundries" - noted several times in the novel - Kate budgets much like Miss K in Hillis's Orchids On Your Budget who owns six purses of different colours and on payday 'puts a certain proportion in each purse, and pays for things accordingly. Black is for Rent, white is for Savings, red is for Clothes, and green, blue and brown cover her other requirements' ${ }^{60}$

Less appealing self-help devotees appear in Loitering with Intent. This novel is also set in the $1950 \mathrm{~s}$ and here, too, the use of first-person narration entails the dissemination of advice. Narrator Fleur Talbot offers wisdom where the impressionable 'English Roses' Beryl and Dottie ('Not that they resembled English roses, far from it; but they were English roses, I felt, in their own minds') offer only prefabricated dicta from the women's magazines. ${ }^{61}$ Beryl recites what she has been told are male preferences: 'Men don't like to see lipstick on the rim of your cup'; 'Men like to see a bit of jewellery on a girl'; 'Men like you to stand up to them' ${ }^{63}$ Dottie voices the emotional clichés that go with that kind of advice: 'Your head rules your heart'; 'I'm only human'. ${ }^{64}$ Underscoring the connection between commodified pseudo-wisdom and aspirational 
femininity, both Beryl's lipstick and Dottie's perfume share the name 'English Rose'. ${ }^{65}$ And so the sardonic Fleur titles her third novel The English Rose.

'I learned a lot in my life from Dottie', Fleur explains, 'by her teaching me some precepts which I could usefully reject' ${ }^{66}$ In contrast to Beryl and Dottie's consumption of decorative and dependent womanliness, Fleur, who is delighted 'to be an artist and a woman in the twentieth century', shares what she has learned about writing and publishing. ${ }^{67}$ Her detachable insights range from thoughts on the creation of character ('I might as well remark here that to make a character ring true it needs must be in some way contradictory, somewhere a paradox') and the uses of autobiography ('complete frankness is not a quality that favours art') to the nature of authors ('I have never known an artist who at some time in his life has not come into conflict with pure evil') and of publishers ('the traditional paranoia of authors is as nothing compared to the inalienable schizophrenia of publishers'). ${ }^{68}$

Spark reflected more directly on self-help in an essay where she recalled her delight at stumbling upon a manual that she never knew she owned, How to Write a Good Letter. Re-reading this book, she finds that 'my novelist's imagination takes over', and contemplates the farcical catastrophe that could ensue were two women friends to receive identically phrased proposals of marriage, thanks to their suitors using the book's model letter; but at least when the women decline, 'An example of the most dignified wording for that occasion is ready to hand in the manual ${ }^{69}{ }^{6}$ What is the relationship between selfhelp and what Spark calls the 'novelist's imagination'? One answer returns us to the moment early in the novel's history when self-help and the novel were almost identical, both navigating what became their familiar course between the circumstantially particular 
and the socially typical. Samuel Richardson's attributed the inspiration for Pamela (1740) to letters serving as models for vulnerable girls sent out in domestic service. Here, we might recall Nancy Hawkins's advice that novels should be written in the style of the familiar letter. The same conversational intimacy remained the signature style of the selfhelp book long after it had parted company with the novel. Indeed, when Spark avoids this form of address entirely, as in her cool, spare, even rebarbative fiction of the 1970s, some of the power of these novels' unsettlingly anonymous narrative address comes from the feeling of a consensus being violated: 'If only it were true that all's well that ends well', is the ominous first line of The Hothouse by the East River (1973): 'if only it were true' ${ }^{70}$ Here, the anti-axiomatic is given an almost axiomatic force of its own; Spark's line stands quotably alone as the novel's entire opening paragraph.

And quotability was once a key feature of the novel. Leah Price argues that the rise of the novel should be understood in relation to the early novel's history of anthologisation, when novels were raided for stand-alone passages of moral insight or descriptive beauty. By this method 'the novel rose piecemeal', Price explains: 'islands of lyric or didactic or sententious collectibles bobbing up occasionally from a sea of dispensable narrative. ${ }^{73}$ The final phase of this process of selective reading produced anthologies such as Wise, Witty, and Tender Sayings in Prose and Verse Selected from the Works of George Eliot, the work of (in Price's rather crushing introduction) 'a sycophantic young Scotsman named Alexander Main' ${ }^{74}$ The Scots had form for this kind of thing, of course, given the nineteenth-century handling of the national novelist, from The Genius and Wisdom of Sir Walter Scott, Comprising Moral, Religious, Political, Literary, and Social Aphorisms, Selected Carefully from His Various Writings (1839) all 
the way through to gift books such as The Waverley Poetical Birthday Book, With Selections from the Poems of Sir Walter Scott, Bart. (1883), Birthday Chimes: Selections from the Poems and Tales of Sir Walter Scott (1891), and The Sir Walter Scott Birthday Book (1897). 'Eighteenth-century anthologists chose excerpts for truth, nineteenthcentury editors for style', Price writes, and she sees in this difference 'the historical shift from didactic to formalist criticism, ${ }^{75}$ By the late nineteenth century there was something virtually unspeakable about the idea that the novel, now attaining the status of a legitimate art form, could be a form of wisdom literature that generates for its reader - in the words of Spark's Fleur Talbot - 'ideas of truth and wonder'. ${ }^{76}$

This may be why Spark's career-long attention to aphorisms and axioms has gone critically unremarked: we have not been in the right historical place to read for it. It seems somehow apt that a novelist famous for her anti-chronological treatment of time might also be a novelist out of her own time, in making her novels contain ('free of charge', 'included in the price of this book') the portable kind of insight that has not been sought in fiction since the Victorian era. So, finally, it is untimely in one sense and altogether timely in another that Spark's centenary year should already have seen the publication of her work in a new form that is also a very old form, Penelope Jardine's anthology, The Observing Eye: The Sayings of Muriel Spark (2018). Those sophisticated summary verdicts of Spark's that critics have not considered noteworthy, ordinary readers may have continued to admire. As narrative theorist Gary Saul Morson writes in his study of the aphorism, 'wise sayings continue to be coined and still play an important part in our lives. As the first philosophy and the first literature, they seem never to go out of style' ${ }^{77}$ 
${ }^{1}$ Muriel Spark, A Far Cry from Kensington (London: Penguin, 1989), p. 83.

${ }^{2}$ Ibid., p.11.

${ }^{3}$ Ibid., p. 11.

${ }^{4}$ Ibid., p. 84 .

${ }^{5}$ Frank Kermode, 'Unrivalled Deftness: The Novels of Muriel Spark’, reprinted in Robert E Hosmer, Jr, Hidden Possibilities: Essays in Honor of Muriel Spark (Notre Dame: University of Notre Dame Press, 2014), p. 108.

${ }^{6}$ Ibid., pp. 109-110.

${ }^{7}$ Muriel Spark, Loitering with Intent (London: Virago, 2012), pp. 114-115.

${ }^{8}$ Walter Benjamin, 'The Storyteller: Reflections on the Works of Nikolai Leskov', in Illuminations, ed. Hannah Arendt, trans Harry Zorn (London: Pimlico, 1999), p. 86.

${ }^{9}$ Ibid., p. 87.

${ }^{10}$ Peter Brooks, Reading for the Plot: Design and Intention in Narrative (Cambridge, MA: Harvard University Press, 1984), p. 27.

${ }^{11}$ Ibid., p. 27, p. 28.

${ }^{12}$ Muriel Spark, 'The Desegregation of Art', The Golden Fleece: Essays, ed. Penelope Jardine (Manchester: Carcanet, 2014), p. 30; Muriel Spark, 'Istanbul', The Golden Fleece, p. 92.

${ }^{13}$ Muriel Spark, The Ballad of Peckham Rye (New York: New Directions, 1999), p. 40, p. 65, p. 66, p. 67.

${ }^{14}$ Muriel Spark, Robinson (London: Macmillan, 1972), p. 57.

${ }^{16}$ Ibid., pp. 22-23.

${ }^{17}$ Dale Carnegie, How to Win Friends and Influence People (New York: Simon and Schuster, 1937), p. 18.

${ }^{18}$ Mrs Dale Carnegie, How to Help Your Husband Get Ahead In His Business and Social Life (Kingswood, Surrey: The World's Work, 1954), pp. 3-7, pp. 8-10.

${ }^{19}$ Carnegie, How to Help Your Husband Get Ahead, p. 57.

${ }^{20}$ Muriel Spark, The Girls of Slender Means (New York: New Directions, 1998), p. 50.

${ }^{21}$ Margery Wilson, The Woman You Want to Be: Margery Wilson's Complete Book of Charm (London: Standard Art Book Co., 1944), p. 52. 
${ }^{22}$ Ibid.

${ }^{23}$ Spark, Girls of Slender Means, p. 42.

${ }^{24}$ Ibid., p. 50.

${ }^{25}$ Muriel Spark, Doctors of Philosophy: A Play (London: Macmillan, 1963), p. 38, pp. 39-40.

${ }^{26}$ Wilson, The Woman You Want to Be, p. 28, p. 23.

${ }^{27}$ Margery Wilson, You're as Young as You Act: A Manual of Movement, Moods and Mannerisms

(Kingswood, Surrey: The World's Work, 1952), p. 74.

${ }^{28}$ Muriel Spark, The Finishing School (New York: Anchor, 2004), p. 109, p. 111.

${ }^{29}$ Wilson, You're as Young as You Act, p. 34, p. 95.

${ }^{30}$ Marjorie Hillis, Live Alone and Like It: The Classic Guide for the Single Woman (London: Virago, 2005),

p. 86.

${ }^{31}$ Ibid., p. 17.

${ }^{32}$ Lisa Hilton, 'Preface' to Hillis, Live Alone and Like It, p. xi. On Hillis's contemporary success, see Joanna Scutts' scholarly and entertaining The Extra Woman: How Marjorie Hillis Led a Generation of Women to Live Alone and Like It (New York: Norton, 2017).

${ }^{33}$ Steven Watts, Self-Help Messiah: Dale Carnegie and Success in Modern America (New York: The Other Press, 2013), p. 131. Barbara Ehrenreich's demolition of 'positive thinking' gives it a religious history: 'If one of the best things you can say about positive thinking is that it articulated an alternative to Calvinism, one of the worst is that it ended up preserving some of Calvinism's more toxic features - a harsh judgmentalism, echoing the old religion's condemnation of sin, and an insistence on the constant interior labor of self-examination.' Barbara Ehrenreich, Smile or Die: How Positive Thinking Fooled America and the World (London: Granta, 2009), p. 89.

${ }^{34}$ Marjorie Hillis, Orchids on Your Budget, or Live Smartly on What Have You (London: Duckworth, 1938), p. 28 .

${ }^{35}$ Ibid., p. 9.

${ }^{36}$ Ibid., p. 125.

${ }^{37}$ Ibid., p. 129.

${ }^{39}$ Leonora Eyles, Sex for the Engaged (London: Robert Hale, 1952), p. 8. 
${ }^{40}$ Hillis, Orchids on Your Budget, p. 164.

${ }^{41}$ Ibid., pp. 164-165.

${ }^{42}$ Marjorie H Roulston (Marjorie Hillis), You Can Start All Over: A Guide for the Widow and Divorcee (New York: Harper \& Brothers, 1951), pp. 62-3.

${ }^{43}$ Ibid., p. 105.

${ }^{44}$ Spark, Doctors of Philosophy, p. 15.

${ }^{45}$ Muriel Spark, Curriculum Vitae: A Volume of Autobiography (London: Penguin, 1993), p. 79.

${ }^{46}$ Muriel Spark, The Prime of Miss Jean Brodie (New York: Perennial, 1999), p. 7.

${ }^{47}$ Ibid., p.124.

${ }^{48}$ Ibid., p. 47.

${ }^{49}$ Ibid., p. 48.

${ }^{50}$ Ibid., p. 10, p. 49.

${ }^{51}$ Ibid., p. 4.

${ }^{52}$ Bernard Levin, The Pendulum Years: Britain and the Sixties (London: Sceptre, 1989), p. 20.

${ }^{53}$ Ibid., p. 11.

${ }^{54}$ Spark, A Far Cry from Kensington, p. 104.

${ }^{55}$ Ibid., p. 5.

${ }^{56}$ Ibid., p. 65, p. 89, p. 93, p. 122, p. 180.

${ }^{57}$ Ibid., p. 35 , p. 40 , p. 77 , p. 81 .

${ }^{58}$ Ibid., p. 40 , p. 52 , p. 53.

${ }^{59}$ Ibid., p. 71.

${ }^{60}$ Ibid., p. 22. Hillis, Orchids On Your Budget, p. 138.

${ }^{61}$ Spark, Loitering with Intent, p. 15

${ }^{63}$ Ibid., p. 16, p. 16, p. 18

${ }^{64}$ Ibid., p. 17, p. 40.

${ }^{65}$ Ibid, p. 16, p. 18.

${ }^{66}$ Ibid., p. 18.

${ }^{67}$ Ibid., p. 15 . 
${ }^{68}$ Ibid., p. 27, p. 77, p. 129, p. 100.

${ }^{69}$ Muriel Spark, 'How to Write a Letter', in The Golden Fleece, p.107, p.108.

${ }^{70}$ Muriel Spark, The Hothouse by the East River (Harmondsworth: Penguin, 1975), p. 5.

${ }^{73}$ Leah Price, The Anthology and the Rise of the Novel: From Richardson to George Eliot (Cambridge:

Cambridge University Press, 2000), pp. 6-7.

${ }^{74}$ Ibid., p. 106.

${ }^{75}$ Ibid., p. 7.

${ }^{76}$ Spark, Loitering with Intent, p. 59.

${ }^{77}$ Gary Saul Morson, The Long and Short of It: From Aphorism to Novel (Stanford: Stanford University Press, 2012), p. 3. 